\title{
Effects of addition of fentanyl and midazolam to local anaesthetic in lumbar epidural anaesthesia for infraumbilical surgeries
}

\author{
Srinivasan S. K. ${ }^{1}$, Dhakshinamoorthy M., ${ }^{2, *}$ Ralleen Jacob. E ${ }^{3}$ \\ ${ }^{1}$ Professor, ${ }^{2}$ Professor, \& HOD, ${ }^{3}$ PG Student, Dept. of Anaesthesiology, Rajah Muthiah Medical College, Annamalai University,
} Chidambaram, Tamil Nadu, India

*Corresponding Author:

Email: mdm.emdeem@gmail.com

Received: $08^{\text {th }}$ June, 2017

Accepted: $24^{\text {th }}$ July, 2017

\begin{abstract}
Introduction: Compared to general anaesthesia, regional anaesthetic techniques are more preferred in lower limb and lower abdominal surgeries as they have many advantages. Fentanyl a short acting opioid agonist, acts at $\mu$ receptor which is hundred times more potent than morphine. Fentanyl has many advantages compared to morphine because of its rapid onset of action and superior intra operative analgesia. Midazolam has an analgesic action by its action on the benzodiazepine GABA A receptor.

Aim: The primary aim of the study was to compare the effect of two adjuncts to $0.5 \%$ bupivacaine through epidural anaesthesia. The study was directed towards the patients posted for infra umbilical surgeries.

Materials and Methods: This study is conducted at Rajah Muthiah Medical College Hospital from august $2015-$ march 2016. Fifty patients posted for elective infra umbilical surgeries were divided into groups of 25 each. Group F received $18 \mathrm{ml}$ of $0.5 \%$ bupivacaine with $2 \mathrm{ml}$ containing $100 \mu \mathrm{g}$ fentanyl and group M received $18 \mathrm{ml}$ of $0.5 \%$ bupivacaine with $2 \mathrm{ml}$ of $2 \mathrm{mg}$ midazolam. Results: Both the groups maintained haemodynamic stability. Onset of sensory block was faster in group F (6.40 min) compared to group M (10.00min) which was statistically significant. The two segment regression time was found to be 150.8 min in group $\mathrm{F}$ compared to $147 \mathrm{~min}$ in group $\mathrm{M}$. The mean duration of postoperative analgesia was significantly prolonged in group $\mathrm{F}$ (293.20min) when compared to group $\mathrm{M}(224.60 \mathrm{~min})$ with significant $\mathrm{P}$ value $(0.05)$

Conclusion: Patients of fentanyl group exhibited prolonged duration of analgesia in comparison to midazolam group. Therefore fentanyl is more suited to midazolam in providing prolonged postoperative analgesia. Epidural fentanyl also produced faster onset of sensory blockade. There were no significant haemodynamic changes in both the groups. The occurance of nausea and vomiting was managed with a single dose of antiemetic.
\end{abstract}

Keywords: Epidural anaesthesia, Fentanyl, Midazolam, Postoperative analgesia.

\section{Introduction}

Compared to general anaesthesia, regional anaesthetic techniques are more preferred in lower limb and lower abdominal surgeries as they have many advantages. Some of the advantages of regional anaesthetic techniques are decreased cardio respiratory complications, decreased plasma catecholamine levels because of decreased surgical stress, early ambulation and thereby decreased incidence of deep vein thrombosis and preserved airway reflexes.

The commonly used local anaesthetics in epidural anaesthesia are bupivacaine and lignocaine. The proof that opioid receptors have been found on the surface of spinal cord, enabled opioids epidural use. ${ }^{1}$ The central neuraxial opioid has been used increasingly because of its merits. The analgesia produced by local anaesthetics is enhanced by the opioids by binding directly to the opiate receptors. Wang et al. (1979) first reported the use of epidural opioids. ${ }^{2}$ Fentanyl and its derivatives have been used most frequently (Lascelles, 2000) ${ }^{3}$ as they have many advantages compared to morphine like its rapid onset of action and superior intra operative analgesia. The availability of preservative free fentanyl has made its use easy in epidural anaesthesia.
Midazolam, exerts its analgesic action on GABA A receptors ${ }^{4}$ in the spinal cord. The GABA A receptor in the spinal cord is involved in nociceptive mechanisms. ${ }^{5}$

\begin{abstract}
Aim
The primary aim of the study was to compare the effect of two adjuncts to $0.5 \%$ bupivacaine through lumbar epidural anaesthesia. The study was directed towards the patients posted for infraumbilical surgeries. The primary aim of the study was achieved by assessing the sensory and motor blockade, along with the duration of postoperative analgesia. The secondary parameters assessed were pulse rate, oxygen saturation, blood pressure and respiratory rate. The side effects of the adjuncts that were added to $0.5 \%$ bupivacaine were also assessed like nausea, vomiting, sedation, urinary retention and pruritus.
\end{abstract}

\section{Materials and methods}

The study was proposed and approval was obtained from the institutional ethical committee. The study was undertaken at the department of anaesthesiology, Rajah Muthiah Medical College Hospital from august 2015 to march 2016. Fifty adult patients of both sexes were chosen. These patients belonged to the age group of 20 - 
60 years. All the patients chosen were under American society of Anaesthesiologists classification I and II. All were posted electively for infraumbilical surgeries. The patients who belonged to class III and IV were excluded. The patients who belonged to the age group apart from the inclusion criteria were excluded. The patients who had bleeding diathesis, infection at the lumbar region were excluded. The patients were divided randomly into two groups of 25 each. This study was done in a double blind fashion. The anaesthetist not involved in the study loaded the study drugs and handed over them to the anaesthetist who was conducting the study. The clinical parameters were noted and monitored by the anaesthetist involved in the study. At the end of the study, decoding was carried out and the results were analysed.

\begin{tabular}{|c|c|l|}
\hline Group $\mathrm{F}$ & 25 patients & $\begin{array}{l}\text { Eighteen } \mathrm{ml} \text { of } 0.5 \% \text { bupivacaine } \\
\text { with } 100 \mu \mathrm{g} \text { fentanyl in } 2 \mathrm{ml}\end{array}$ \\
\hline Group $\mathrm{M}$ & 25 patients & $\begin{array}{l}\text { Eighteen } \mathrm{ml} \text { of } 0.5 \% \text { bupivacaine } \\
\text { with } 2 \mathrm{mg} \text { midazolam in } 2 \mathrm{ml}\end{array}$ \\
\hline
\end{tabular}

Informed consent was obtained from the patients and they were explained about the anaesthetic technique. The patients were kept nil orally from 10 pm before the day of surgery. A histamine 2 blocker ranitidine $150 \mathrm{mg}$ and an anxiolytic diazepam $10 \mathrm{mg}$ were administered as oral premedication on the day before surgery. The patients were shifted to operative room and the baseline heart rate and blood pressure were noted. The patient was positioned either in left lateral or by sitting depending upon the type of surgery. Local anaesthetic skin infiltration in L3 - L4 inter space was done after adopting thorough asepsis. A 16 gauge Tuohy's needle was used to identify epidural space by standard technique. Three $\mathrm{ml}$ of $2 \%$ lignocaine with adrenaline was injected as a test dose. Eighteen ml of $0.5 \%$ bupivacaine with $2 \mathrm{ml}$ of the study drug was administered. The patient was then placed in the supine position. The vital parameters were monitored every two minutes for first 10 minutes and then every 5 minutes till the end of the surgery. Once the surgery got over, the patient was transferred to recovery ward and monitoring was done up to 4 hours postoperatively. Once the patients were stable, they were shifted to ward. The following parameters were studied.

1. Dermatomal sensory blockade

2. Duration of analgesia

3. Intensity of motor blockade( using modified bromage scale)

\begin{tabular}{|c|l|c|}
\hline Grade & \multicolumn{1}{|c|}{ Criteria } & Degree of block \\
\hline I & Free movement of legs and feet & None \\
\hline II & $\begin{array}{l}\text { Just able to flex knees with free } \\
\text { movement of feet }\end{array}$ & Partial 33\% \\
\hline III & $\begin{array}{l}\text { Unable to flex knees, but with } \\
\text { free movement of feet }\end{array}$ & Partial 66\% \\
\hline IV & Unable to move legs or feet & Complete paralysis \\
\hline
\end{tabular}

1. Degree of pain postoperatively was evaluated using VAS pain distress scale at an interval of 30 minutes up to 24 hours.

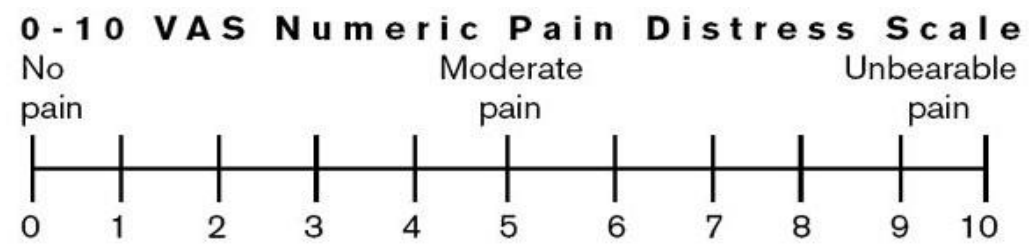

2. The time of administration of rescue analgesic was recorded.

3. Any neurological deficits, bowel and bladder dysfunction were noted for 24 hours in the postoperative period.

At the end of study, the data were compiled and subjected to statistical analysis using students paired " $t$ " test and chi square test. The significance of the study was calculated using " $p$ " value. $(\mathrm{p}<0.05=$ significant $)$ 


\section{Observations and results}

\section{Demographic data analysis}

Table 1: Age, Weight, Height Distribution between two groups

\begin{tabular}{|l|c|c|c|c|c|c|}
\hline \multirow{2}{*}{ Variables } & \multicolumn{2}{|c|}{ Group- F } & \multicolumn{2}{c|}{ Group- M } & \multirow{2}{*}{ t value } & \multirow{2}{*}{ p value } \\
\cline { 2 - 5 } & Mean & S.D. & Mean & S.D. & & \\
\hline Age $(\mathrm{yrs})$ & 41.96 & 15.501 & 45.16 & 14.727 & 0.748 & 0.458 \\
\hline Weight $(\mathrm{Kg})$ & 54.20 & 3.512 & 56.40 & 3.512 & 2.189 & 0.073 \\
\hline Height $(\mathrm{cms})$ & 159.20 & 6.371 & 157.24 & 5.883 & -1.130 & 0.264 \\
\hline
\end{tabular}

The anthropometric variables between the two groups were not significant statistically.

\section{Sensory Block:}

Table 2: Sensory blockade characteristics between two groups.

\begin{tabular}{|l|c|c|c|c|c|c|}
\hline \multirow{2}{*}{ Variables (min) } & \multicolumn{2}{|c|}{ GROUP- F } & \multicolumn{2}{c|}{ GROUP- M } & \multirow{2}{*}{ t value } & p value \\
\cline { 2 - 7 } & Mean & S.D. & Mean & S.D. & & \\
\hline Sensory block Onset & 6.40 & 1.118 & 10.00 & 1.732 & 8.731 & $<0.001$ \\
\hline $\begin{array}{l}\text { Two segment } \\
\text { regression time }\end{array}$ & $\begin{array}{c}150.8 \\
0\end{array}$ & $\begin{array}{c}13.20 \\
4\end{array}$ & 147.00 & 13.540 & -1.005 & 0.320 \\
\hline
\end{tabular}

Table 3: Duration of postoperative analgesia between two groups

\begin{tabular}{|l|c|c|c|c|c|c|}
\hline \multirow{2}{*}{ Variables (min) } & \multicolumn{2}{|c|}{ Group F } & \multicolumn{2}{c|}{ Group M } & t value & p value \\
\cline { 2 - 7 } & Mean & S.D. & Mean & S.D. & & \\
\hline $\begin{array}{l}\text { Duration of } \\
\text { postoperative } \\
\text { analgesia }\end{array}$ & 293.20 & 28.390 & 224.60 & 21.981 & -9.573 & $<0.001$ \\
\hline
\end{tabular}

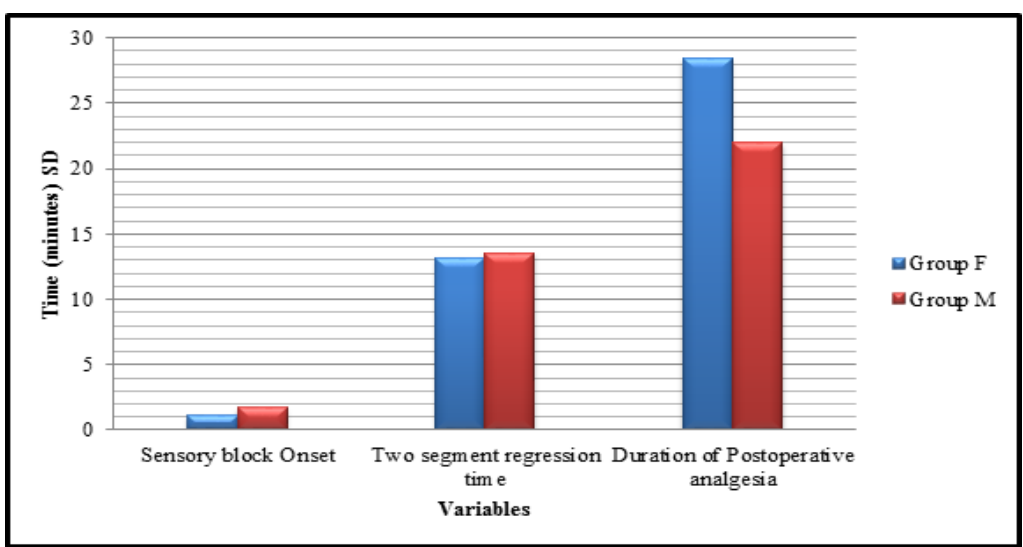

Fig. 1: Sensory blockade characteristics between two groups

Group F patients showed quicker onset of sensory block. The postoperative analgesia was longer in fentanyl group patients. Regarding two segment regression time, no significant deviation was observed.

\section{Motor block:}

Table 4: Percentage of motor block in both groups

\begin{tabular}{|l|c|c|c|c|c|c|}
\hline \multirow{2}{*}{ Motor Block } & \multicolumn{2}{|c|}{ Group F } & \multicolumn{2}{c|}{ Group M } & Chi- & P value \\
\cline { 2 - 6 } & $\begin{array}{c}\text { No. of } \\
\text { patients }\end{array}$ & $\%$ & $\begin{array}{c}\text { No. of } \\
\text { patients }\end{array}$ & $\%$ & & \\
\hline $\begin{array}{l}\text { Unable to flex } \\
\text { knees but with } \\
\text { free movement of }\end{array}$ & 9 & $36 \%$ & 6 & $24 \%$ & & \\
\hline
\end{tabular}




\begin{tabular}{|l|c|c|c|c|c|c|}
\hline $\begin{array}{l}\text { the feet - Grade } \\
\text { III }\end{array}$ & & & & & 0.857 & 0.355 \\
\cline { 1 - 1 } $\begin{array}{l}\text { Unable to move } \\
\text { both knee and feet } \\
- \text { Grade IV }\end{array}$ & 16 & $64 \%$ & 19 & $76 \%$ & & \\
\hline
\end{tabular}

In Group F, 9 patients had incomplete motor blockade while 16 patients had complete blockade as compared to 6 patients who had incomplete blockade in group M and 19 patients who had complete blockade in group M. There was no significant deviation between the two groups.

There were no significant changes in other parameters like mean pulse rate, mean arterial pressure and respiratory rate.

\section{Side effects:}

\section{Table 5: Side effects}

\begin{tabular}{|l|c|c|c|c|}
\hline Side effects & \multicolumn{2}{|c|}{ Group F } & \multicolumn{2}{c|}{ Group M } \\
\hline & Patients & \% & Patients & \% \\
\hline Nausea & 10 & 40 & 4 & 16 \\
\hline Vomiting & 4 & 16 & & \\
\hline Urinary retention & - & & - & \\
\hline Pruritus & - & & 5 & 20 \\
\hline Hypotension & - & & - & \\
\hline Sedation & 20 & $80 \%$ & 20 & $80 \%$ \\
\hline
\end{tabular}

Incidence of nausea and vomiting was noted in 14 patients in group $\mathrm{F}(56 \%)$ and 4 patients in group $\mathrm{M}(16 \%)$. A single dose of antiemetic was sufficient to treat the nausea and vomiting. Five patients (20\%) in group M developed pruritus. No intervention was required. The sedation level was comparable between the two groups.

\section{Discussion}

The epidural anaesthesia is one of the commonly used regional techniques for both intraoperative and postoperative pain management. ${ }^{7}$ Epidural anaesthesia using a single injection of $0.5 \%$ bupivacaine will provide good perioperative analgesia and muscle relaxation with graded hypotension and decreased blood loss by causing motor, sensory and sympathetic blockade, hence gaining popularity ever since its introduction.

Epidural administration of various analgesics gained increasing popularity following the discovery of opioid receptors in the spinal cord capable of producing potent analgesia as reported by Taksh and Rudy in 1976. Opioid receptors in the dorsal horn have pre synaptic and post synaptic effects and affect the modulation of nocioceptive input, but does not cause sympathetic or motor blockade. Several opiates have been successfully used for epidural postoperative analgesia. ${ }^{8}$ The efficacy of epidural morphine is well known. It's undesirable side effects have led the clinician search for other safe opioids for epidural administration. ${ }^{9}$

Search for "better" epidural analgesics led to the discovery of fentanyl, a $\mu$ receptor agonist synthetic opioid analgesic. Following epidural administration, fentanyl had been shown to provide satisfactory analgesia in postoperative period and well documented. ${ }^{10}$ The present study was conducted on fifty adult patients divided into two groups of 25 each. Fentanyl is a highly lipid soluble narcotic agonist with a relatively short duration of action when used intravenously in small doses, and in vitro penetrates duramater more rapidly than any other narcotic ${ }^{(11)}$. The time taken for a drug to diffuse across the duramater is one of the determinants of the rapidity of onset of analgesia. Fentanyl when administered through epidural crosses duramater and binds to spinal opioid receptors. It is absorbed systemically and binds to supra spinal opioid receptors to produce analgesia. ${ }^{12}$

The aim of this study was to compare the efficacy of midazolam and fentanyl when used as adjuncts to epidural administration of bupivacaine for perioperative analgesia in infraumbilical surgeries.

Mean time for onset of sensory block is noted as $06.40 \mathrm{~min}$ in group $\mathrm{F}$ and $10.00 \mathrm{~min}$ in group $\mathrm{M}$, which was statistically significant, $(\mathrm{p}<0.001)$. Johnson et $\mathrm{al}^{13}$ compared epidural bupivacaine $0.5 \%$ and epidural bupivacaine $0.5 \%$ plus fentanyl $75 \mu \mathrm{g}$ and concluded that bupivacaine plus fentanyl produced analgesia with short latency of $06.80 \mathrm{~min}$ which is closer to our observation of 06.40 min. Suraj Dhale and Vaishali Shelgaonkar ${ }^{14}$ studied different doses of epidural fentanyl $(25 \mu \mathrm{g}, 50 \mu \mathrm{g}, 75 \mu \mathrm{g})$ with $0.5 \%$ bupivacaine for perioperative analgesia and found that $50 \mu \mathrm{g}$ had a quicker onset of analgesia within $09.53 \mathrm{~min}$ which is closer to our observation. The mean two segment regression time was found to be 150.80 min in group $\mathrm{F}$ 
patients and $147.00 \mathrm{~min}$ in Group M patients which was found to be statistically significant. The two segment regression time in both the groups were comparable as reported by Singh H \& Yang J et al. ${ }^{15}$ Both the groups maintained haemodynamic stability which was statistically insignificant and there were no significant changes in respiratory parameters in either of the groups during perioperative period.

Ozalp. G, Gruner. F, Kuru. $\mathrm{N}^{16}$ concluded that epidural fentanyl was associated with stable haemodynamics with fewer side effects and excellent in providing postoperative analgesia when compared to epidural morphine .

Alpa Patel et $\mathrm{al}^{17}$ found that $2 \mathrm{mg}$ of epidural midazolam gave a satisfactory postoperative pain relief and less respiratory depression which was similar to our study. Incidence of nausea and vomiting was more in group F (56\%) compared to group M (16\%). Twenty percentage of patients in group $\mathrm{M}$ developed pruritus which was mild in nature and did not require any intervention. Observations of the study done by D. Kumar et $\mathrm{al}^{18}$ and Hayashi $\mathrm{H}$ et al ${ }^{19}$ also correlated with our study.

Duration of postoperative analgesia was significantly longer in group F (293.20min) when compared to group M (224.60min). So, Fentanyl scored over midazolam in offering longer duration of analgesia. This was similar to the study conducted by Dhale et al 2000. ${ }^{20}$ The sedation score level was comparable between the two groups.

\section{Conclusion}

Patients of fentanyl group exhibited prolonged duration of analgesia in comparison to midazolam group. Therefore fentanyl is more suited to midazolam in providing prolonged postoperative analgesia. Epidural fentanyl also produced faster onset of sensory blockade. There were no significant haemodynamic changes in both the groups. The occurrence of nausea and vomiting was managed with a single dose of antiemetic.

\section{References}

1. Klide A.M. (1992): Epidural anaesthesia. Veterinary Clinics of North America Small Animal Practice, 22,413416.

2. Wang J.K., Nauss L.E., Thomas J.E. (1979): Pain relief by intrathecally applied morphine in man.

Anaesthesiology, 50,149-51.

3. Lascelles B.D.X. (2000): Clinical pharmacology of analgesic agents. In: Hellebrekers L.J. (ed.): Animal Pain. Van der Wees, Utrecht, 85-116

4. Goodchild CS, Serrao JM. Intrathecal midazolam in the rat: evidence for spinally-mediated analgesia. $\mathrm{Br} \mathbf{J}$ Anaesth 1987;59:1563-70.

5. Edwards M, Serrao JM, Gent JP, Goodchild CS. On the mechanism by which midazolam causes spinally mediated analgesia. Anaesthesiology 1990;73:273-7.

6. Goodchild CS, Noble J. The effects of intrathecal midazolam on sympathetic nervous system reflexes in man - a pilot study. Br I Clin Pharmacol 1987;23:279-85.
7. Bromage $\mathrm{P}$, Comporesi E, Chestnut D. Epidural narcotics for postoperative analgesia. Anesth Analg 1980;59:473.

8. Koshy T, Afzal L and Kaur B. A comparison of epidural Morphine and epidural Buprenorphine for post-operative Analgesia: A double blind study. Ind J Anaesth. 1994;42:305.

9. Kay B. A double blind comparison of morphine and buprenorphine in the prevention of pain after operation. Br J Anaesth 1978;50:605.

10. Rutter OV, Skewes DG, Morgan M: Extradural opioids for post operative analgesia; A double blind comparison of pethidine, fentanyl and morphine. Br J Anaesthesia 1981;53:915.

11. Moore RA, Bullingham RSJ, Hand CW, Aspel JB, Allen MC, Thomas D: Dural permeability to narcotics. In vitro determination and application to extradural administration, Br J Anaesthesia 1982;54:1117-28.

12. D'Angelo R, Gerancher JC, Eisenach JC, Raphael BL. Epidural fentanyl produces labor analgesia by a spinal mechanism. Anesthesiology. 1998 Jun; 88(6):1519-23.

13. Johnson C, Oriold N, Feinstein D, Ransil BJ, Onset of action between bupivacaine $0.5 \%$ and bupivacaine $0.5 \%$

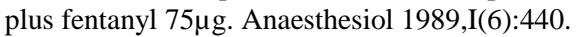

14. Suraj Dhale, Vaishali Shelgaonkar, V.V Akulwar. A comparative study of epidural bupivacaine and epidural bupivacaine with fentanyl for perioperative analgesia. Ind J Anaesthesia.2000 May;7(2):44-55.

15. Singh H. Yang J, Thornton K, Giesecke AH, Epidural / Intrathecal Fentanyl prolongs sensory block of bupivacaine. Can J. Anasthe. 1995,42:987-91.

16. Ozalp G, Guner F, Kuru N, Kadiogullari N. Postoperative patient-controlled epidural analgesia with opioid bupivacaine mixtures. Can J Anaesth. 1998 Oct;45(10):938-42.

17. Alpa Patel, N. Desai. Indian Journal of Clinical Anaesthesia, January - March 2015;2(1):15-18

18. D.Kumar, Dev Gupta. Comparative study of epidural buprenorphine and ketamine for postoperative pain relief. Ind. Journal Anaesthesia. 1997 Aug;41(3):38-49.

19. Hayashi H, Nishiuchi T, Tamura H, Takeda K. Comparison of buprenorphine and fentanyl for postoperative pain relief by continuous epidural infusion. Anaesthesia. 1993 Dec;42(12):1763-8.

20. Dhale, Shelgaonicar, Akulwar, Ghosh: Comparative study of epidural bupivacaine. Ind. J. Anaesthesia(44) 35,2000 . 